\title{
Before and after hip fracture, vitamin D deficiency may not be treated sufficiently
}

\author{
S. Maier • E. Sidelnikov • B. Dawson-Hughes • A. Egli • R. Theiler • \\ A. Platz • H. B. Staehelin • H-P. Simmen • C. Meier • W. Dick • D. Grob • \\ A. von Eckardstein $\cdot$ H. A. Bischoff-Ferrari
}

Received: 23 January 2013 / Accepted: 10 April 2013 / Published online: 29 May 2013

(C) International Osteoporosis Foundation and National Osteoporosis Foundation 2013

\begin{abstract}
Summary Our findings show that only about $20 \%$ of seniors receive vitamin $\mathrm{D}$ supplementation prior to their index hip fracture or after the event. We further confirm the high prevalence of severe vitamin D deficiency in this population and show that those who receive supplementation have significantly higher 25-hydroxyvitamin D (25(OH)D) status.

Introduction The aim of this study is to assess current practice in pre- and post-hip fracture care practice with respect to vitamin $\mathrm{D}$ supplementation.

Methods We surveyed 1,090 acute hip fracture patients age 65 and older admitted to acute care for hip fracture repair; 844 had serum 25-hydroxyvitamin D levels measured upon admission to acute care, and 362 agreed to be followed at 12 month after their hip fracture. Prevalence of vitamin D supplementation was assessed upon admission to acute care (at the time of hip fracture), upon discharge from acute care, and at 6 and 12 months follow-up.
\end{abstract}

S. Maier $\cdot$ E. Sidelnikov $\cdot$ A. Egli $\cdot$ H. A. Bischoff-Ferrari $(\square)$ Centre on Aging and Mobility, University of Zurich and Waid City Hospital, Department of Geriatrics and Aging Research,

University Hospital Zurich, Gloriastrasse 25,

CH-8091, Zurich, Switzerland

e-mail: Heike.Bischoff@usz.ch

\section{S. Maier}

Department of Orthopedic Surgery, Cantonal Hospital St. Gallen,

St. Gallen, Switzerland

B. Dawson-Hughes

USDA Human Nutrition Research Center on Aging, Tufts

University, Boston, MA, USA

R. Theiler

Department of Rheumatology, City Hospital Triemli, Zurich, Switzerland

A. Platz

Department of Traumatology, City Hospital Triemli, Zurich, Switzerland
Results Of 1,090 acute hip fracture patients (mean age 85 years, $78 \%$ women, $59 \%$ community-dwelling), $19 \%$ had received any dose of vitamin D prior to the index hip fracture, $27 \%$ (of 854 assessed) at discharge from acute care, $22 \%$ (of 321 assessed) at 6 month, and $21 \%$ (of 285 assessed) at 12 month after their hip fracture. At the time of fracture, $45 \%$ had 25(OH)D levels below $10 \mathrm{ng} / \mathrm{ml}, 81 \%$ had levels below $20 \mathrm{ng} / \mathrm{ml}$, and $96 \%$ had levels below $30 \mathrm{ng} / \mathrm{ml}$. Notably, 25(OH)D levels did not differ by season or gender but were significantly higher among 164 hip fracture patients, with any vitamin D supplementation compared with 680 without supplementation (19.9 versus $10.8 \mathrm{ng} / \mathrm{ml} ; p<0.0001$ ).

Conclusion Only about $20 \%$ of seniors receive vitamin D at the time of their fracture and after the event. This is despite the documented $81 \%$ prevalence of vitamin D deficiency. Interdisciplinary efforts may be warranted to improve vitamin D supplementation in seniors both before a hip fracture occurs and after.

H. B. Staehelin

Department of Geriatrics, University of Basel, Basel, Switzerland

H.-P. Simmen

Department of Traumatology, University Hospital, Zurich, Switzerland

C. Meier

Department of Traumatology, City Hospital Waid, Zurich, Switzerland

W. Dick

Department of Orthopedic Surgery, Basel University Hospital, Basel, Switzerland

D. Grob

Department of Geriatrics, City Hospital Waid, Zurich, Switzerland

A. von Eckardstein

Institute of Clinical Chemistry, University Hospital Zurich, Zurich, Switzerland 
Keyword 25-hydroxyvitamin D · Clinical care · Cohort study · Elderly · Hip fracture · Vitamin D deficiency

\section{Introduction}

Hip fractures are the most common fractures among seniors age 75 and older [1, 2]. Hip fractures are also the most serious fractures: up to $50 \%$ of seniors will have a permanent functional disability; and within the first 12 month after the fracture, $30-50 \%$ will be readmitted to acute care [3], 15 to $30 \%$ will require long-term nursing home care, and up to $20 \%$ will die [1, 3-6]. The exponential increase in hip fractures after age 75 translates into an estimated 1 in 3 women and 1 in 6 men, who will have sustained a hip fracture by their 90th decade [7]. Consequently, with the increase of the senior segment of the population, hip fractures account for substantial and increasing health care expenses, both in the US [8] and in Europe [9-11].

Supplemental vitamin D has been shown to reduce both falls [12] and hip fractures [13] by about $30 \%$, summarized in recent meta-analyses of double-blind randomized clinical trials (RCTs), a benefit documented in community-dwelling and institutionalized older seniors. Notably, both in the meta-analysis of 8 RCTs among 2,426 seniors on fall prevention [12] and the pooled analysis of participant level data of 11 RCTs among 31,022 seniors on fracture prevention [12], there was a dose threshold of about $800 \mathrm{IU}$ vitamin D per day required for the effective reduction of both endpoints. This is consistent with recommended vitamin D intake by the institute of medicine [14], the international osteoporosis foundation $[15,16]$, the US endocrine society [17], and the Swiss department of health [18].

It is thus concerning that despite the existing evidence with respect to vitamin D reflected in recent recommendations, the prevalence of vitamin D deficiency among hip fracture has been found to be about $80 \%$, with $60 \%$ meeting the criteria of severe vitamin D deficiency (serum concentrations below $10 \mathrm{ng} / \mathrm{ml}$ ) [19, 20]. Notably, severe vitamin D deficiency may cause osteomalacia [21], and histologic osteomalacia has been found to be common in several hip fracture case studies (12-44\%) [22-27].

In this study, we review the clinical application of vitamin D supplementation in a large sample of acute hip fracture patients before and after hip fracture. We also assess their serum 25-hydroxyvitamin D $(25(\mathrm{OH}) \mathrm{D})$ concentrations upon admission to acute care, explore seasonal variations for these concentrations, and investigate whether subgroups of hip fracture patients are more likely to receive supplementation with vitamin D. Finally, to further understand clinical practice procedures, we ask general practitioners why they did not prescribe vitamin D after the hip fracture event.

\section{Methods}

Participants

We surveyed all consecutive 1,090 acute hip fracture patients aged 65 or older, who were admitted to one large hospital center (Triemli City Hospital, Zurich, Switzerland) between January 2005 and March 2010. The survey was done as a part of screening procedure for a clinical trial of early rehabilitation after hip fracture [3]. Of the screened hip fracture patients, 173 were eligible and agreed to participate in the clinical trial; the details of the trial design and its inclusion/exclusion criteria were published elsewhere [3]. All other patients were offered participation in a cohort study (hip fracture cohort), and 362 agreed to be followed for 1 year, with 2 phone calls at 6 (information on bone-related therapies) and 12 months (full follow up phone call) after their hip fracture. To evaluate the reasons why hip fracture patients do not receive vitamin D after their hip fracture, we performed a small substudy among the 263 cohort participants, who were not receiving supplemental vitamin D at discharge from the hospital. We contacted these people 6 months after their hip fracture, and asked whether they were prescribed vitamin D supplements. Of 252 seniors who denied prescription of vitamin $\mathrm{D}$, we identified the primary physician in 143, and sent these primary physicians a simple questionnaire to evaluate why they did not prescribe vitamin D supplementation. Of 143 letters sent out to general practitioners, we received a response from $118(83 \%)$. For their response, general practitioners received a small reimbursement of 20 Swiss Francs. Our study was approved by the ethical commission at the Kanton Zurich, and participants gave their written informed consent.

\section{Variables}

For all screened hip fracture patients: those who participated in the clinical trial $(n=173)$, those who participated in the cohort $(n=362)$, and those who did not participate in either $(n=555)$, demographic characteristics were abstracted from the medical records. Cognitive function of all patients was assessed with the mini mental state examination [28] during acute care after hip fracture repair. Detailed information on received medications was recorded at baseline for all participants, and at discharge, and 12 months only for the cohort participants. The 173 trial participants received 800 or 2,000 IU vitamin D per day as the intervention over a 12 month follow-up [3] and were excluded from the post-hip fracture vitamin D supplementation assessment. Medication information including 
vitamin D supplements was evaluated and cross-checked by two investigators (S.M.; A.E.).

\section{5-Hydroxyvitamin D measurement}

Serum samples for 25-hydroxyvitamin D measurement were available from 844 of 1,090 acute hip fracture patients. All samples were analyzed at the Institute of Clinical Chemistry at the University of Zurich using the automated DiaSorin Liaison assay for the 25-hydroxyvitamin D assessment.

\section{Statistical analysis}

Participants of the clinical trial, the cohort study, and the patients who were surveyed but did not participate in the trial or the cohort were compared with respect to important potential confounders using one-way ANOVA for continuous and $\chi^{2}$ test for categorical variables.

Information from all 1,090 patients was used to evaluate factors that could prevent seniors from receiving vitamin D supplementation before their hip fracture. The patients recruited for the clinical trial $(n=173)$ received vitamin $\mathrm{D}$ supplementation as a part of their study treatment and were excluded from the analyses of the risk factors at discharge. Only those who participated in the hip fracture cohort $(n=$ 362) were followed up beyond discharge, so the analyses for the 12-month time point was limited to these participants only. During the 12-month follow up, 34 cohort participants died, and 43 dropped out or were lost to follow up, bringing the sample size at 12 months to $n=285$.

Logistic regression was used to evaluate associations between population characteristics and the likelihood of receiving any vitamin $\mathrm{D}$ supplementation and the minimum recommended dose of vitamin D (800 IU). A separate model was fitted for each of the investigated time points: admission, discharge, and 12 months after the fracture.

All statistical analyses were performed in SAS v. 9.2 statistical software (Copyright $($ ) 2002-2008 by SAS Institute Inc., Cary, NC, USA), and two-sided $p$ value of 0.05 was used as a threshold for statistical significance.

\section{Results}

\section{Descriptive}

Table 1 summarizes the three groups of acute hip fracture patients (173 trial participants, 362 hip fracture cohort participants, and 555 hip fracture patients who were not recruited for either), with respect to important potential confounders. Hip fracture patients were on average $85.1(\mathrm{SD}=7.1)$ years old, $78 \%$ were women, mean body mass index was $23.2(\mathrm{SD}=4.3) \mathrm{kg} / \mathrm{m}^{2}$, $48 \%$ had moderate to severe cognitive function impairment (mini mental examination score $<15$; the classic diagnostic range for the MMSE is $0-10=$ severe cognitive impairment, $11-20=$ moderate cognitive impairment, $21-26=$ mild cognitive impairment, and $27-30=$ normal [29]), $59 \%$ of patients lived at home before the index hip fracture, and $54 \%$ were discharged to their home, after the fracture has been repaired.

\section{5-Hydroxyvitamin D serum concentrations}

Upon admission to acute care and reflecting serum $25(\mathrm{OH}) \mathrm{D}$ concentration at the time of their hip fracture, mean $25(\mathrm{OH}) \mathrm{D}$ concentrations were $12.6(\mathrm{SD}=8.7) \mathrm{ng} / \mathrm{ml}$ among 844 seniors, with measurements; $96 \%$ of study participants had serum vitamin D levels below $30 \mathrm{ng} / \mathrm{ml}$ (threshold of optimal fracture reduction [13, 15, 17, 30]), $80 \%$ had levels below $20 \mathrm{ng} / \mathrm{ml}$ (deficiency [14]), and $52 \%$ had levels below $10 \mathrm{ng} / \mathrm{ml}$ (severe deficiency [21]). Notably, as illustrated in Fig. 1, there were no significant seasonal variations of serum $25(\mathrm{OH}) \mathrm{D}$ concentration $(p=0.30)$ in this sample of seniors with acute hip fracture, and levels did not differ by gender (199 men had a mean level of $11.8 \mathrm{ng} / \mathrm{ml}$, 645 women had a mean level of $12.8 \mathrm{ng} / \mathrm{ml} ; p=0.10$ ). However, 164 hip fracture patients who received any dose of vitamin D supplementation had significantly higher 25(OH)D serum concentrations compared with 680 without supplementation (19.9 versus $10.8 \mathrm{ng} / \mathrm{ml} ; p<0.0001)$.

\section{Prevalence of vitamin D supplementation}

Only $19 \%$ of the acute fracture patients received vitamin D at the time of their hip fracture. The proportion of patients who were prescribed vitamin $\mathrm{D}$ increased to $27 \%$ at discharge, then fell back to $22 \%$ at 6 months and $21 \%$ at 12 month follow-up (Table 2 and Fig. 2). The most common treatment strategy was vitamin D plus calcium supplementation, and very few patients received additional pharmacologic treatment (Table 2). Of those who received vitamin D supplementation, the current recommendation of $800 \mathrm{IU}$ per day was only received by $55 \%$ prior to the index hip fracture, by $57 \%$ at discharge, by $55 \%$ at 6 months, and by $47 \%$ at 12 month follow-up.

Women were prescribed vitamin D more often than men, before their index hip fracture and at discharge from acute care, as well as at 12 month follow-up $(\mathrm{OR}=2.26 ; 95 \%$ C.I. $1.45-3.53, \mathrm{OR}=1.78 ; 95 \%$ C.I. $1.17-2.70$, and $\mathrm{OR}=2.61$; $95 \%$ C.I. 1.04-6.55, respectively; Table 3). The association between female gender and prevalence of vitamin D supplementation was significant at all time points and independent of age, cognitive function, and type of dwelling.

The association between type of dwelling and prevalence of vitamin D supplementation varied with time. Before the index hip fracture, seniors were equally likely to receive vitamin D supplementation, regardless of whether they lived 
Table 1 Characteristics of study population

\begin{tabular}{|c|c|c|c|c|c|}
\hline Characteristic & Clinical trial $(n=173)$ & $\begin{array}{l}\text { Hip fracture cohort } \\
\text { participants }(n=362)\end{array}$ & $\begin{array}{l}\text { Screened only } \\
(n=555)\end{array}$ & $p^{\dagger}$ & All $n=1,090)$ \\
\hline Women & $\begin{array}{l}137 \\
(79.2 \%)\end{array}$ & $\begin{array}{l}284 \\
(78.5 \%)\end{array}$ & $\begin{array}{l}427 \\
(76.9 \%)\end{array}$ & 0.77 & $\begin{array}{l}848 \\
(77.8 \%)\end{array}$ \\
\hline Age, years. & $\begin{array}{l}84.2 \\
(6.9)\end{array}$ & $\begin{array}{l}84.4 \\
(7.0)\end{array}$ & $\begin{array}{l}85.8 \\
(7.1)\end{array}$ & 0.002 & $\begin{array}{l}85.1 \\
(7.1)\end{array}$ \\
\hline Body mass index, $\mathrm{kg} / \mathrm{m}^{2}$ & $\begin{array}{l}24.3 \\
(4.3)\end{array}$ & $\begin{array}{l}23.6 \\
(4.1)\end{array}$ & $\begin{array}{l}22.6 \\
(4.3)\end{array}$ & $<0.0001$ & $\begin{array}{l}23.2 \\
(4.3)\end{array}$ \\
\hline \multicolumn{6}{|l|}{ Mini mental examination score ${ }^{\pi}$} \\
\hline$<15$ & $\begin{array}{l}0 \\
(0 \%)\end{array}$ & $\begin{array}{l}143 \\
(39.5 \%)\end{array}$ & $\begin{array}{l}379 \\
(68.3 \%)\end{array}$ & $<0.0001^{*}$ & $\begin{array}{l}522 \\
(48.0 \%)\end{array}$ \\
\hline $15+$ & $\begin{array}{l}170 \\
(100 \%)\end{array}$ & $\begin{array}{l}219 \\
(60.5 \%)\end{array}$ & $\begin{array}{l}176 \\
(31.7 \%)\end{array}$ & & $\begin{array}{l}565 \\
(52.0 \%)\end{array}$ \\
\hline \multicolumn{6}{|l|}{ Admitted from } \\
\hline Home & $\begin{array}{l}134 \\
(77.5 \%)\end{array}$ & $\begin{array}{l}217 \\
(60.1 \%)\end{array}$ & $\begin{array}{l}290 \\
(52.7 \%)\end{array}$ & $<0.0001$ & $\begin{array}{l}641 \\
(59.1 \%)\end{array}$ \\
\hline Nursing/old age home & $\begin{array}{l}39 \\
(22.5 \%)\end{array}$ & $\begin{array}{l}144 \\
(39.9 \%)\end{array}$ & $\begin{array}{l}260 \\
(47.3 \%)\end{array}$ & & $\begin{array}{l}443 \\
(40.9 \%)\end{array}$ \\
\hline \multicolumn{6}{|l|}{ Discharged to } \\
\hline Home (inkl. rehab.) & $\begin{array}{l}133 \\
(76.9 \%)\end{array}$ & $\begin{array}{l}212 \\
(58.7 \%)\end{array}$ & $\begin{array}{l}243 \\
(44.3 \%)\end{array}$ & $<0.0001$ & $\begin{array}{l}588 \\
(54.3 \%)\end{array}$ \\
\hline Nursing/old age home & $\begin{array}{l}37 \\
(21.4 \%)\end{array}$ & $\begin{array}{l}146 \\
(40.4 \%)\end{array}$ & $\begin{array}{l}247 \\
(45.0 \%)\end{array}$ & & $\begin{array}{l}430 \\
(39.7 \%)\end{array}$ \\
\hline Deceased during acute care & $\begin{array}{l}3 \\
(1.7 \%)\end{array}$ & $\begin{array}{l}3 \\
(0.9 \%)\end{array}$ & $\begin{array}{l}59 \\
(10.7 \%)\end{array}$ & & $\begin{array}{l}65 \\
(6.0 \%)\end{array}$ \\
\hline Length of acute hospitalization, days & $\begin{array}{l}12.5 \\
(8.8)\end{array}$ & $\begin{array}{l}16.7 \\
(29.5)\end{array}$ & $\begin{array}{l}15.9 \\
(31.08)\end{array}$ & 0.27 & $\begin{array}{l}15.6 \\
(28.6)\end{array}$ \\
\hline $\begin{array}{l}\text { Serum } 25(\mathrm{OH}) \mathrm{D} \text { level, } \mathrm{ng} / \mathrm{ml}^{* *} \text { at the } \\
\text { time of hip fracture }\end{array}$ & $\begin{array}{l}12.6 \\
(7.9)\end{array}$ & $\begin{array}{l}13.1 \\
(8.5)\end{array}$ & $\begin{array}{l}12.3 \\
(9.0)\end{array}$ & 0.50 & $\begin{array}{l}12.6 \\
(8.7)\end{array}$ \\
\hline \multicolumn{6}{|l|}{ Categories of serum $25(\mathrm{OH}) \mathrm{D}$ level** } \\
\hline$<10 \mathrm{ng} / \mathrm{ml}$ & $\begin{array}{l}76 \\
(45.2 \%)\end{array}$ & $\begin{array}{l}136 \\
(50.0 \%)\end{array}$ & $\begin{array}{l}224 \\
(55.5 \%)\end{array}$ & 0.17 & $\begin{array}{l}436 \\
(51.7 \%)\end{array}$ \\
\hline $10-19 \mathrm{ng} / \mathrm{ml}$ & $\begin{array}{l}59 \\
(35.1 \%)\end{array}$ & $\begin{array}{l}79 \\
(29.0 \%)\end{array}$ & $\begin{array}{l}107 \\
(26.5 \%)\end{array}$ & & $\begin{array}{l}245 \\
(29.0 \%)\end{array}$ \\
\hline $20-29 \mathrm{ng} / \mathrm{ml}$ & $\begin{array}{l}29 \\
(17.3 \%)\end{array}$ & $\begin{array}{l}46 \\
(16.9 \%)\end{array}$ & $\begin{array}{l}54 \\
(13.3 \%)\end{array}$ & & $\begin{array}{l}129 \\
(15.3 \%)\end{array}$ \\
\hline $30+\mathrm{ng} / \mathrm{ml}$ & $\begin{array}{l}4 \\
(2.4 \%)\end{array}$ & $\begin{array}{l}11 \\
(4.1 \%)\end{array}$ & $\begin{array}{l}19 \\
(4.7 \%)\end{array}$ & & $\begin{array}{l}34 \\
(4.0 \%)\end{array}$ \\
\hline \multicolumn{6}{|c|}{ Any dose of vitamin D prior to index hip fracture } \\
\hline Yes & $\begin{array}{l}19 \\
(11.0 \%)\end{array}$ & $\begin{array}{l}75 \\
(20.7 \%)\end{array}$ & $\begin{array}{l}112 \\
(20.2 \%)\end{array}$ & 0.01 & $\begin{array}{l}206 \\
(18.9 \%)\end{array}$ \\
\hline No & $\begin{array}{l}154 \\
(89.0 \%)\end{array}$ & $\begin{array}{l}287 \\
(79.3 \%)\end{array}$ & $\begin{array}{l}442 \\
(79.8 \%)\end{array}$ & & $\begin{array}{l}883 \\
(81.1 \%)\end{array}$ \\
\hline
\end{tabular}

(Asterisk) continuous variables are given as mean (SD), categorical variables - as frequency (percentage), (dagger) based on one-way ANOVA for continuous variables, $\chi^{2}$-test for categorical variables, (pilcrow sign) MMSE data on three clinical trial participants are missing, (double dagger) $P$ value compares cohort participants to screened only patients (173 clinical trial participants are excluded from the analysis), and (double asterisk) serum 25(OH)D concentrations were measured in 844 participants: clinical trial $n=168$, cohort study $n=272$, and screened patients $n=404$

at home or in a nursing home. However, after the index hip fracture, patients who were discharged to a nursing home were only half as likely to receive vitamin D supplementation compared to those who were discharged home $(\mathrm{OR}=$ 


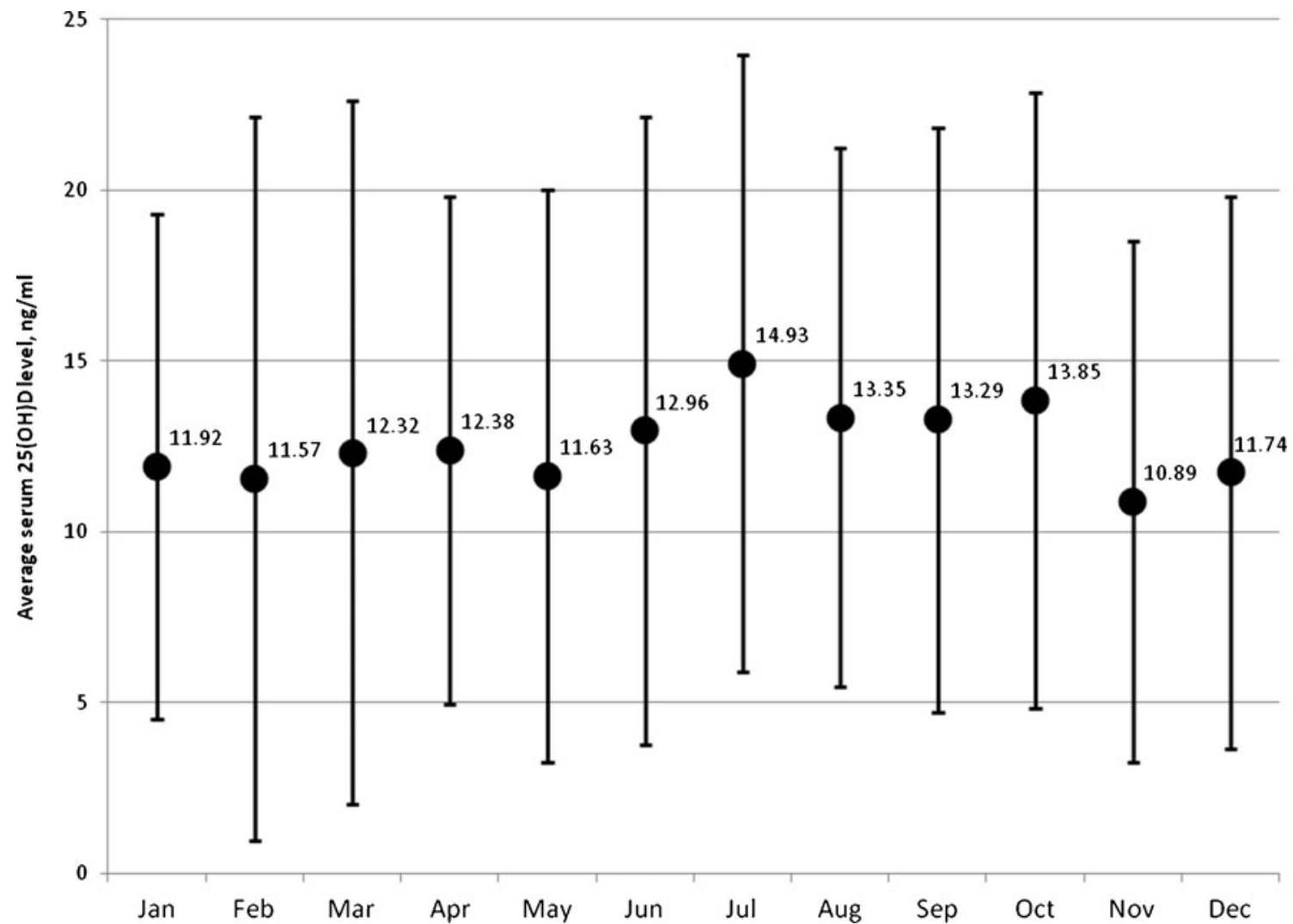

Fig. 1 Average serum $25(\mathrm{OH}) \mathrm{D}$ concentration at the time of hip fracture and by month of measurement. Dots represent the average $25(\mathrm{OH}) \mathrm{D}$ serum concentration at the time of hip fracture (admission to

0.50; $95 \%$ C.I. $0.35-0.71$ ); and also at 12 months, nursing home residents were $59 \%$ less likely to receive vitamin D supplementation compared to seniors living at home at this time, although this did not reach statistical significance (OR $=0.63 ; 95 \%$ C.I. $0.30-1.32$; Table 3 ). Higher age and lower cognitive function were not significant barriers for receiving vitamin D supplementation at any time point (Table 3). acute care) in $\mathrm{ng} / \mathrm{ml}$ and by month of measurement. Whiskers depict one standard deviation above and below the monthly average

Why general practitioners did not prescribe vitamin D supplementation after hip fracture

In a small substudy at 6 month follow-up, we identified 252 participants of the cohort study who were not supplemented with vitamin D. Furthermore, we identified and sent letters to 143 of their general practitioners, including a short
Table 2 Prevalence of vitamin D supplementation at the time of hip fracture, at discharge from acute care, and at 6 and 12 month follow-up

(Asterisk) clinical trial participants and patients who died in hospital are excluded. (Dagger) limited to cohort study participants only

\begin{tabular}{lllll}
\hline Treatment & $\begin{array}{l}\text { At time of hip } \\
\text { fracture } \\
(n=1,090)\end{array}$ & $\begin{array}{l}\text { At discharge from acute } \\
\text { care } \\
(n=854)^{*}\end{array}$ & $\begin{array}{l}6 \text { months } \\
(n=321)^{\dagger}\end{array}$ & $\begin{array}{l}12 \text { months } \\
(n=285)^{\dagger}\end{array}$ \\
\hline No vitamin D supplement & 884 & 628 & 252 & 226 \\
Vitamin D only & $(81.1 \%)$ & $(73.5 \%)$ & $(78.5 \%)$ & $(79.3 \%)$ \\
& 1 & 3 & 2 & 3 \\
Vitamin D and calcium & $(0.1 \%)$ & $(0.3 \%)$ & $(0.6 \%)$ & $(1.1 \%)$ \\
& 161 & 174 & 56 & 45 \\
Vitamin D and & $(14.8 \%)$ & $(20.4 \%)$ & $(17.4 \%)$ & $(15.8 \%)$ \\
bisphosphonate & 2 & 3 & 0 & 1 \\
Vitamin D alone or in & $(0.2 \%)$ & $(0.3 \%)$ & $(0 \%)$ & $(0.4 \%)$ \\
combination & 206 & 226 & 69 & 59 \\
& $(18.9 \%)$ & $(26.5 \%)$ & $(21.5 \%)$ & $(20.7 \%)$ \\
\hline
\end{tabular}




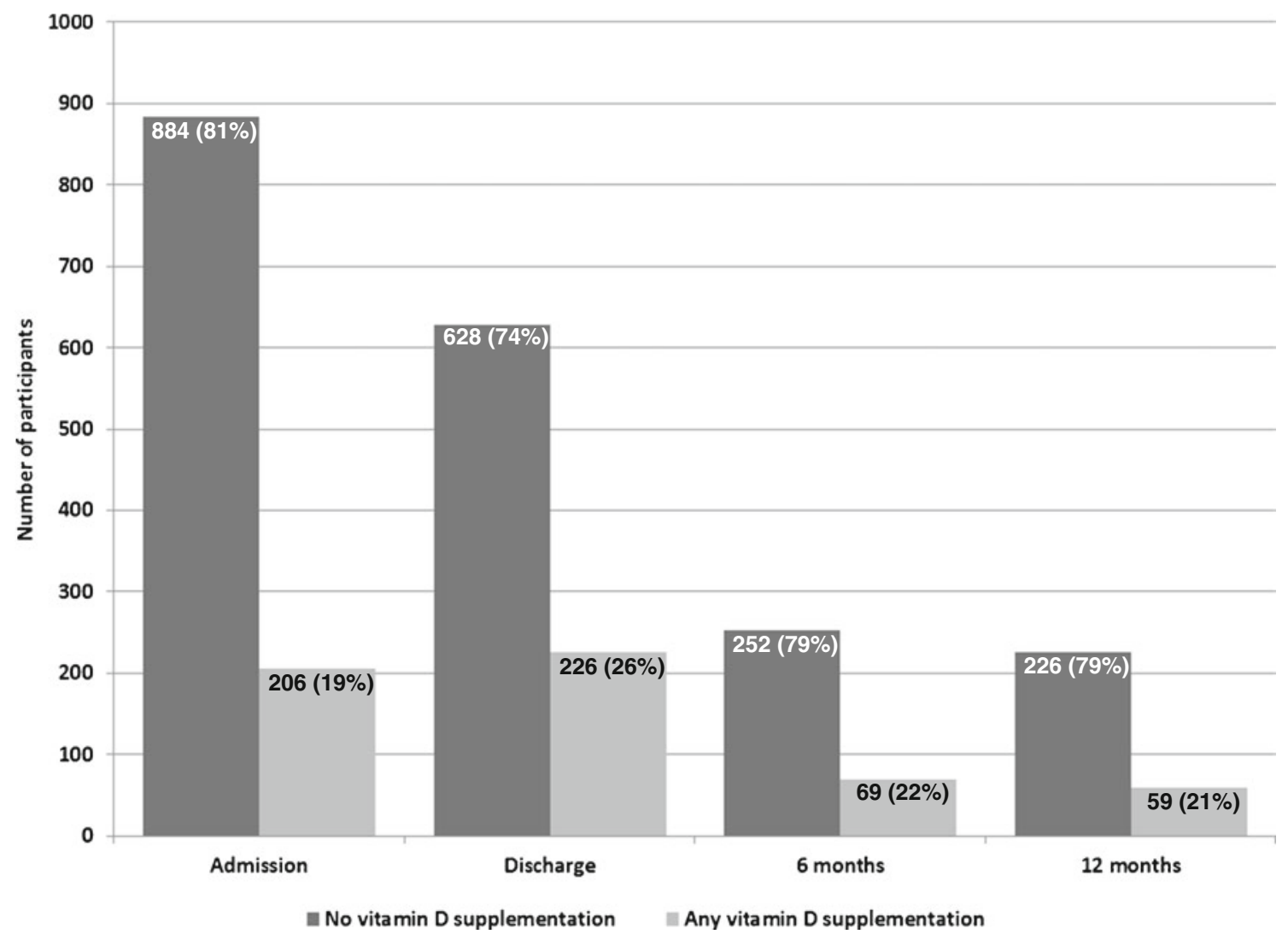

Fig. 2 Prevalence of vitamin D Supplementation of any dose at the time of hip fracture (admission to acute care), at discharge, and 6 and 12 months of follow-up. If we restrict this assessment to the 285 patients assessed at 12 months, $58(20 \%)$ received vitamin D prior

to admission due to the index fracture and $65(23 \%)$ received vitamin $\mathrm{D}$ at 6 months. If we restrict this assessment to the 321 patients assessed at 6 months, $70(22 \%)$ received vitamin D prior to admission due to the index fracture

questionnaire for them to state why they did not prescribe vitamin D to their patients who had a hip fracture. Of 143 letters sent out, we got a response from $118(83 \%)$ general practitioners. The two main reasons for not prescribing vitamin D after the hip fracture of their patients were: "Vitamin D was not prescribed at discharge" (53\%) and "the patient does not want to take vitamin D" (20\%).

\section{Discussion}

With our study, we describe clinical application of vitamin D supplementation in a large sample of hip fracture patients, both at the time of their index hip fracture and after the event. We show that supplementation is low prior to the index hip fracture and remains low after the event. About $80 \%$ of hip fracture patients were not supplemented at any time point in our study. Notably, we further confirm the high prevalence of severe vitamin D deficiency in this population; confirm that 25-hydroxyvitamin D levels in hip fracture patients are low also in the summer season, and that the $20 \%$ who receive supplementation have significantly higher 25 -hydroxyvitamin D levels. Finally, our substudy at 6 month follow-up among general practitioners of not supplemented hip fracture patients provides insight into why vitamin $\mathrm{D}$ is not prescribed even after a hip fracture occurred. As the main reason stated was "not mentioned in the discharge letter from acute care", our data suggest that surgeons need to become key partners of post-hip fracture care as their recommendation, or lack of recommendation is, according to our data, critical to whether hip fracture patients receive vitamin $\mathrm{D}$ or not.

Mean 25-hydroxyvitamin D serum concentrations among 844 hip fracture patients of this study were $12.6 \mathrm{ng} / \mathrm{ml} ; 80 \%$ were vitamin D deficient, and $52 \%$ were severely deficient. Furthermore, 25-hydroxyvitamin D levels upon admission to acute care remained low in each month of the year, without a significant rise during summer months. These data confirm that hip fracture patients are most vulnerable to vitamin D deficiency and need supplementation independent of season. Moreover, the $19 \%$ of patients who had any dose of supplementation prior to their hip fracture had significantly higher 25-hydroxyvitamin D levels, suggesting that supplementation is effective as expected from a large number of intervention studies in this population [31, 32].

The high prevalence of severe vitamin D deficiency documented in our study suggests that clinical care with 
Table 3 Adjusted associations between population characteristics and likelihood of receiving any dose of vitamin D per day (yes vs. no)

\begin{tabular}{|c|c|c|c|}
\hline Baseline characteristic & At the time of hip fracture $(n=1,081)^{\dagger}$ & At discharge from acute care ${ }^{\star}(n=848)$ & 12 months $\left(n=154^{* *}\right)$ \\
\hline \multicolumn{4}{|l|}{ Gender } \\
\hline Male (Ref.) & - & - & - \\
\hline \multirow[t]{2}{*}{ Female } & 2.26 & 1.78 & 2.61 \\
\hline & $(1.45-3.53)$ & $(1.17-2.70)$ & $(1.04-6.55)$ \\
\hline \multicolumn{4}{|l|}{ Age, years. } \\
\hline $65-84$ (Ref.) & - & - & - \\
\hline \multirow[t]{2}{*}{$85+$} & 1.10 & 1.01 & 0.95 \\
\hline & $(0.80-1.52)$ & $(0.73-1.40)$ & $(0.46-1.97)$ \\
\hline \multicolumn{4}{|l|}{ Mini mental status (MMS) } \\
\hline$\geq 15$ (Ref.) & - & - & - \\
\hline \multirow[t]{2}{*}{$<15$} & 1.15 & 1.05 & 0.93 \\
\hline & $(0.80-1.66)$ & $(0.74-1.49)$ & $(0.41-2.09)$ \\
\hline \multicolumn{4}{|l|}{ Dwellings } \\
\hline Home (Ref.) & - & - & - \\
\hline \multirow[t]{2}{*}{ Nursing/old age home } & 1.01 & 0.50 & 0.63 \\
\hline & $(0.72-1.42)$ & $(0.35-0.71)$ & $(0.30-1.32)$ \\
\hline
\end{tabular}

(Asterisk) all associations are adjusted for gender, age, cognitive function at baseline, and type of dwelling (home or institutionalized); associations for admission and discharge are additionally adjusted for the patient group (NFP-53, cohort study, or screened only). Analysis for 12 months of follow up is limited to the hip fracture cohort participants. (Dagger) effective sample sizes are given for each time point. Some participants were excluded from the models due to missing values in one or more of the predictors. (Double dagger) RCT participants are excluded, (double asterisk) living condition at 12 month follow-up was missing on 131 patients; and since it was a logistic model, these patients were excluded from the model, bringing the effective sample size to 154 . All other covariates in the model have complete information on the entire sample size of 285

respect to vitamin D supplementation both at the time of and after hip fracture needs additional improvement. To further guide clinical care, we investigated whether subgroups of hip fracture patients are less likely to receive vitamin D supplementation. Notably, before and after the index hip fracture and independent of other covariates, men were significantly less likely to receive vitamin D supplementation, although men and women had similarly low 25hydroxyvitamin D levels. This may have traditional reasons, based on which men are thought to be at low risk of fracture. However, more recent data show that among individuals age 60 years and older, the mortality-adjusted residual lifetime risk of fracture is $44-65 \%$ for women and $25-42 \%$ for men [33]. Furthermore, the benefit of vitamin D supplementation is confirmed for both men and women in recent meta-analyses of fall and fracture prevention [13, 30, 34]. Also, hip fracture patients discharged to a nursing home after the index hip fracture were $50 \%$ less likely to receive vitamin D supplementation in our study, independent of other covariates. This speaks to a double standard of care of nursing home and communitydwelling seniors, which is not supported by the evidence from the recent pooled analyses of double-blind RCTs, where both community-dwelling $(-32 \%)$ and institutionalized $(-30 \%)$ seniors benefited significantly from high dose vitamin D supplementation (median $800 \mathrm{IU} /$ day) in the prevention of hip fractures [13].
Adding to the case for vitamin D supplementation after hip fracture, vitamin D supplementation reduced hospital readmission in the first year after hip fracture significantly by $39 \%$ as demonstrated in the 173 trial participants [3] of this study, independent of gender and type of dwelling. Furthermore, in a secondary analysis of the same trial population, baseline 25 -hydroxyvitamin $\mathrm{D}$ level was a significant predictor of mortality in the first 12 months after hip fracture, with a significant $7 \%$ reduction in the risk of mortality per $1 \mathrm{ng} / \mathrm{ml}$ higher 25-hydrocyvitamin D status (per $1 \mathrm{ng} / \mathrm{ml}$ : HR=0.93; $95 \%$ CI 0.87-0.998; $p=0.04$ ).

In a small substudy, we evaluated at the general practitioners level why senior hip fracture patients did not receive supplementation. Notably, the main reason for not prescribing vitamin $\mathrm{D}$ in their patients who sustained a hip fracture was that this was not recommended in the discharge letter of acute care. This information may be important, regarding the choice of network partners of post-hip fracture care, which according to our data should include traumatologists and orthopedic surgeons, as they may have an important impact on whether vitamin D is prescribed after hip fracture.

Our study has several strengths. The study population included 1,090 consecutive hip fracture patients with assessment of 25 -hydroxyvitamin D levels in 844 confirming the broad prevalence of deficiency and lack of seasonality as observed in other studies of similar populations [20,35-38]. Moreover, our initial sample can be linked to the results of a 
double-blind RCT among the 173 trial participants who were part of the 1,090 hip fracture patients surveyed in our study [3]. Finally, we extend the assessment of vitamin D supplementation in clinical practice to reasons why supplementation is not prescribed at the general practitioner level. This study also has limitations, as we were able to include only a subsample at the 12 month follow-up assessment. However, gender distribution and mean 25-hydroxyvitamin D status were similar in the 427 hip fracture patients who were prescreened but not enrolled into the cohort study or the trial. Also, we adjusted our analyses for the covariates that showed a variation between the three groups of participants (age, cognitive status, and type of dwelling).

In summary, our results show that vitamin D supplementation needs further support in its translation into clinical practice, both in the primary prevention of hip fractures and in post-hip fracture care. Efforts to improve vitamin D supplementation in post-hip fracture care will need an interdisciplinary approach, including traumatology and orthopedic surgery to set up vitamin D supplementation strategies effectively. Currently, overall vitamin D supplementation is too low, especially so in senior men and nursing home residents.

\section{Conflicts of interest None.}

\section{References}

1. Cummings SR, Kelsey JL, Nevitt MC, O’Dowd KJ (1985) Epidemiology of osteoporosis and osteoporotic fractures. Epidemiol Rev 7:178-208

2. Bischoff-Ferrari HA, Orav JE, Barrett JA, Baron JA (Sep 2007) Effect of seasonality and weather on fracture risk in individuals 65 years and older. Osteoporos Int 18(9):12251233

3. Bischoff-Ferrari HA, Dawson-Hughes B, Platz A et al (2010) Effect of high dosage cholecalciferol and extended physiotherapy on complications after hip fracture: a randomized controlled trial. Arch Intern Med 170(9):813-820

4. Magaziner J, Hawkes W, Hebel JR et al (2000) Recovery from hip fracture in eight areas of function. J Gerontol A Biol Sci Med Sci 55(9):M498-507

5. Tinetti ME, Williams CS (1997) Falls, injuries due to falls, and the risk of admission to a nursing home. N Engl J Med 337(18):1279-1284

6. Schaller F, Sidelnikov E, Theiler R et al (Sep 2012) Mild to moderate cognitive impairment is a major risk factor for mortality and nursing home admission in the first year after hip fracture. Bone 51(3):347-352

7. Birge SJ, Morrow-Howell N, Proctor EK (Nov 1994) Hip fracture. Clin Geriatr Med 10(4):589-609

8. Cummings SR, Rubin SM, Black D (1990) The future of hip fractures in the US. Numbers, costs, and potential effects of postmenopausal estrogen. Clin Orthop 252:163-166

9. Schurch MA, Rizzoli R, Mermillod B, Vasey H, Michel JP, Bonjour JP (Dec 1996) A prospective study on socioeconomic aspects of fracture of the proximal femur. J Bone Miner Res 11(12):1935-1942

10. Cawston H, Maravic M, Fardellone P et al (2012) Epidemiological burden of postmenopausal osteoporosis in France from 2010 to 2020: estimations from a disease model. Arch Osteoporos 7(12):237-46

11. Lippuner K, Golder M, Greiner R (Mar 2005) Epidemiology and direct medical costs of osteoporotic fractures in men and women in Switzerland. Osteoporos Int 16(Suppl 2):S8-S17

12. Bischoff-Ferrari HA, Dawson-Hughes B, Staehelin HB et al (2009) Fall prevention with supplemental and alpha-hydroxylated vitamin D: a meta-analysis of randomized controlled trial. Br Med J 339:b3692. doi:10.1136/bmj.b3692, BMJ. 2009 Oct 1

13. Bischoff-Ferrari HA, Orav EJ, Willett WC et al (2012) A pooled analysis of vitamin $\mathrm{D}$ dose requirements for fracture prevention. $\mathrm{N}$ Engl J Med 367(1):40-9

14. IOM (2010) Dietary Reference Ranges for Calcium and Vitamin D. http://www.iom.edu/Reports/2010/Dietary-Reference-Intakesfor-Calcium-and-Vitamin-D.aspx (access Feb13.2012)

15. Dawson-Hughes B, Mithal A, Bonjour JP et al (2010) IOF position statement: vitamin $\mathrm{D}$ recommendations for older adults. Osteoporos Int 21(7):1151-1154

16. Bischoff Ferrari HA (2011) Three steps to unbreakable bones: the 2011 World Osteoporosis Day Report. http://www.iofbonehealth.org// WOD_11/WOD11-Report.pdf (access june 3rd 2012)

17. Holick MF, Binkley NC, Bischoff-Ferrari HA et al (Jul 2011) Evaluation, treatment, and prevention of vitamin d deficiency: an endocrine society clinical practice guideline. J Clin Endocrinol Metab 96(7):1911-1930

18. Schweiz BfS (2012) http://www.bfs.admin.ch/bfs/portal/de/index/ themen/01/03/blank/key/ind erw.html. access: 25.5 .2012

19. Bischoff-Ferrari HA, Can U, Staehelin HB et al (Mar 2008) Severe vitamin $\mathrm{D}$ deficiency in Swiss hip fracture patients. Bone 42(3):597-602

20. LeBoff MS, Kohlmeier L, Hurwitz S, Franklin J, Wright J, Glowacki J (1999) Occult vitamin D deficiency in postmenopausal US women with acute hip fracture. JAMA 281(16):1505-1511

21. Holick MF (2007) Vitamin D, deficiency. N Engl J Med 357(3):266-281

22. Harma M, Parviainen M, Koskinen T, Hoikka V, Alhava E (1987) Bone density, histomorphometry, and biochemistry in patients with fractures of the hip or spine. Ann Clin Res 19(6):378-382

23. Bhan A, Rao AD, Rao DS (2010) Osteomalacia as a result of vitamin D deficiency. Endocrinol Metab Clin North Am 39(2):321-331, table of contents

24. Aaron JE, Gallagher JC, Nordin BE (1974) Seasonal variation of histological osteomalacia in femoral neck fractures. Lancet 2(7872):84-85

25. Arnala I, Kyrola K, Kroger H, Alhava EM (1997) Analysis of 245 consecutive hip fracture patients with special reference to bone metabolism. Ann Chir Gynaecol 86(4):343-347

26. Wilton TJ, Hosking DJ, Pawley E, Stevens A, Harvey L (May 1987) Osteomalacia and femoral neck fractures in the elderly patient. J Bone Joint Surg Br 69(3):388-390

27. Wilton TJ, Hosking DJ, Pawley E, Stevens A, Harvey L (Nov 1987) Screening for osteomalacia in elderly patients with femoral neck fractures. J Bone Joint Surg Br 69(5):765-768

28. Cockrell JR, Folstein MF (1988) Mini mental state examination (MMSE). Psychopharmacol Bull 24(4):689-692

29. Folstein MF, Folstein SE, McHugh PR (1975) Mini mental state: a practical method for grading the cognitive state of patients for the clinician. J Psychiatr Res 12(3):189-198

30. Bischoff-Ferrari HA, Willett WC, Wong JB et al (2009) Prevention of nonvertebral fractures with oral vitamin $\mathrm{D}$ and dose dependency: a meta-analysis of randomized controlled trials. Arch Intern Med 169(6):551-561 
31. Bischoff-Ferrari HA, Shao A, Dawson-Hughes B, Hathcock J, Giovannucci E, Willett WC (Jul 2010) Benefit-risk assessment of vitamin D supplementation. Osteoporos Int 21(7):1121-1132

32. Gallagher JC, Sai A, Templin T 2nd, Smith L (2012) Dose response to vitamin D supplementation in postmenopausal women: a randomized trial. Ann Intern Med 156(6):425-437

33. Nguyen ND, Ahlborg HG, Center JR, Eisman JA, Nguyen TV (2007) Residual lifetime risk of fractures in women and men. J Bone Miner Res 12:12, Mar 12

34. Bischoff-Ferrari HA, Dawson-Hughes B, Staehelin HB et al (2009) Fall prevention with supplemental and active forms of vitamin D: a meta-analysis of randomized controlled trials. BMJ 339(1):b3692

35. Chan R, Chan CC, Woo J et al (2011) Serum 25-hydroxyvitamin $\mathrm{D}$, bone mineral density, and nonvertebral fracture risk in community-dwelling older men: results from Mr. Os, Hong Kong. Arch Osteoporos 6(1-2):21-30, Dec

36. Bakhtiyarova S, Lesnyak O, Kyznesova N, Blankenstein MA, Lips P (2006) Vitamin D status among patients with hip fracture and elderly control subjects in Yekaterinburg, Russia. Osteoporos Int 17(3):441-446

37. Nurmi I, Kaukonen JP, Luthje P et al (Dec 2005) Half of the patients with an acute hip fracture suffer from hypovitaminosis D: a prospective study in southeastern Finland. Osteoporos Int 16(12):2018-2024

38. Inderjeeth CA, Barrett T, Al-Lahham Y, Mulford J, Nicklason F, Reberger C (2002) Seasonal variation, hip fracture, and vitamin $\mathrm{D}$ levels in southern Tasmania. $\mathrm{N} Z$ Med $\mathrm{J}$ 115(1152):183-185 